\title{
Multi-Variable Individual Heating Conditions Tested in Parallel Provide Rapid Process Optimization on the Prelude® X
}

\author{
Daniel Martinez, James P. Cain, Elizabeth Restituyo-Rosario, Katya \\ Karankevich, Peter Bergwall, and Nathaniel Cosper
}

Protein Technologies, Inc., Tucson, AZ, 85714, USA, Website: www.ptipep.com, Email: info@ptipep.com

\section{Introduction}

Despite their high selectivity and low toxicity compared to their small molecule counterparts, a pressing problem when looking at the design of peptide drugs is their poor oral bioavailability and short in vivo half-life. Significant progress has been made to address the disadvantages of peptide drugs through modifications such as head-to-tail cyclization, backbone $N$-methylation, and "stapling" through a ring-closing metathesis (RCM) reaction, all of which can increase the synthetic difficulty. The application of heat represents an additional tool to optimize the production of challenging synthetic peptides, and a new heating technology, induction heating, has been introduced on the Prelude X. Induction heating allows for independent, simultaneous and rapid heating of multiple reactors with increased efficiency. Different heating conditions, at $25^{\circ} \mathrm{C}, 60^{\circ} \mathrm{C}$ and $90^{\circ} \mathrm{C}$ were used for the synthesis of the difficult JR(1-10)peptide (Figure 1) [1].

\section{Trp-Phe-Tyr-Tyr-Leu-Ile-Thr-Ile-Met-NH2}

Fig. 1. Sequence of JR(1-10) peptide synthesized with heat on the Prelude X® platform.

\section{Results and Discussion}

Experimental results show a vast improvement in crude purity as temperature was increased. The highest purity was found for the synthesis at $90^{\circ} \mathrm{C}$. Compared to $25^{\circ} \mathrm{C}, 90^{\circ} \mathrm{C}$ produced a $51 \%$ improvement in the purity. From the tested conditions, applying heat at $90^{\circ} \mathrm{C}$ improved crude purity more than four-fold when compared to the synthesis performed at room temperature (Figure 2). Importantly, rapid process optimization was attained through the use of independently heated parallel synthesis.
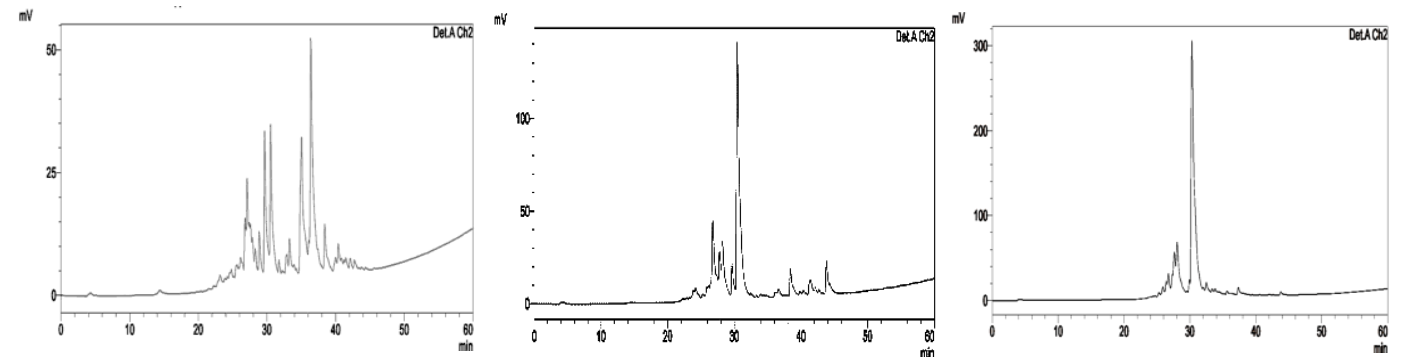

Fig. 2. HPLC traces of JR(1-10) peptide synthesized with heat on the Prelude X® platform at $25^{\circ} \mathrm{C}$, $60^{\circ} \mathrm{C}$ and $90^{\circ} \mathrm{C}$ (left to right).

\section{References}

1. Redemann, T., Jung, G. In Ramage, R., Epton, R., Eds., Peptides 1996, Proceedings of the 24th European Peptide Symposium, Mayflower Scientific Ltd, Kingswinford, UK, 1998, p. 749. 